\title{
Awareness, Education and Capacity Building of Stakeholders for Successful Implementation of Access and Benefit Sharing Regime
}

\author{
Sabiha Alam ${ }^{1}$, Hasrat Arjjumend*2 \\ ${ }^{1}$ MMAJ Academy of International Studies, Jamia Millia Islamia (Central University), New Delhi - \\ 110025, India. E-mail: sabiha.alam@ @otmail.com \\ ${ }^{2}$ Centre for International Sustainable Development Law, Montreal (Quebec) H3A 1X1, Canada. E-mail: \\ harjjumend@gmail.com \\ *Corresponding author
}

How to cite this paper: Alam, S. and Arjjumend, H. (2018). Awareness, Education and Capacity Building of Stakeholders for Successful Implementation of Access and Benefit Sharing Regime. Grassroots Journal of Natural Resources, 1(1): 37-45. Doi:

https://doi.org/10.33002/nr2581.6853.01014

Received: 08 July 2018

Reviewed: 26 July 2018

Provisionally Accepted: 27 July 2018

Revised: 28 July 2018

Finally Accepted: 31 July 2018

Published: 13 August 2018

Copyright (C) 2018 by author(s) and

The Grassroots Institute.

This work is licensed under the Creative Commons Attribution International License (CC BY 4.0). http://creativecommons.org/licenses/by/4.0/
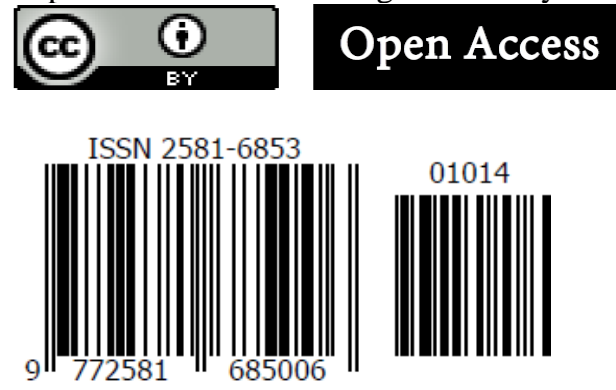

\begin{abstract}
To popularize the concept of access and benefit sharing (ABS) and Nagoya Protocol, mass awareness and education are crucial. The present awareness/educational efforts of concerned government authorities in most of the cases are inadequate. Moreover, an intensive awareness campaign is necessary to educate the Indigenous people and local communities (ILCs) and other concerned stakeholders. An opinion survey of Indigenous organizations and competent national authorities of 12 Asian countries had been conducted to understand the field implications of relevant provisions of Nagoya Protocol. While some countries are found committed, it was found that there is lot to be learnt for all the countries regarding awareness-raising about Nagoya Protocol and ABS. Similarly, the capacity building of different layers of stakeholders is given some priorities by many Parties at national level. Capacity building efforts are being undertaken at regional level as well, e.g. South-East Asia level, Africa level, Western Europe level, etc. It has been noticed that in certain pockets the ILCs are active players in the capacity building efforts, while in other countries they are just passive recipients of such efforts. Still there is a long way to go for the successful implementation of $\mathrm{ABS}$ regimes globally.
\end{abstract}

Keywords

ABS; Capacity Building; ILCs; Nagoya Protocol 


\section{Introduction}

The Nagoya Protocol on access and benefit sharing (ABS) came into existence in 2010 and was enacted in October 2012. A range of provisions of the Nagoya Protocol, including Articles 5(2), 5(5), 6(3), 8, 15(1) and 16(1), specifically oblige Parties to formulate, enact and implement the domestic legislation, policies, administrative measures and governance systems in support of rights of indigenous people and local communities (ILCs). Additionally, Articles 5, 6(2), 7, 8, 12 and 18(2) of the Nagoya Protocol require domestic legislation relating to ABS including establishment of prior informed consent (PIC), mutually agreed terms, and recognition of laws, customs, and institutions of ILCs. In relation to sharing of the benefits, Article 5(2) of Nagoya Protocol clearly says, "each Party is obliged to take legislative, administrative, or policy measures to ensure that benefits arising from the utilisation of genetic resources as well as subsequent application and commercialisation are shared fairly and equitably with the providing Party". Both the provider and user Parties, in this context, need to adequately educate various stakeholders in respective countries. But, to comply with the international legal obligations, States are required to promulgate domestic legislation, policies, administrative measures or related frameworks. In over half a decade (as of June 2018), out of 105 Parties to the Nagoya Protocol, ${ }^{1}$ only64 countries including European Union members had uploaded their domestic ABS legislation, policy or administrative measures to the Convention on Biological DiversityCBD's ABS Clearinghouse. ${ }^{2}$ Of these 64 countries, 28 EU member countries ${ }^{3}$ have adopted EU legislation on ABS enacted in 2014, and 13 of these 28 EU countries have also enacted their own ABS laws and policies. ${ }^{4}$ The other 36 nations that have created and submitted their ABS instruments to the ABS Clearinghouse are Albania, Antigua \& Barbuda, Belarus, Bhutan, Brazil, Burkina Faso, Burundi, Cameroon, Costa Rica, Democratic Republic of Congo, Côte d'Ivoire, Dominican Republic, Ecuador, Ethiopia, Guatemala, Honduras, India, Japan, Kenya, Lao, Madagascar, Malawi, Mauritania, Mexico, Morocco, Niger, Norway, Panama, Peru, Republic of Moldova, Senegal, South Africa, Switzerland, Togo, Uganda and Vietnam.

Article $22^{5}$ of Nagoya Protocol addresses the awareness raising, education and capacity building of various stakeholders. In order to address the contemporary issues that came onto the fore, the education and empowerment of ILCs appears critical. Further, the education and awareness about a new concept like ABS are quite crucial for implementation on the ground level. Since the ABS and Nagoya Protocol are both very recent concepts and even the government authorities need immense education about it before other stakeholders. UN Convention on Biological Diversity (CBD) has facilitated and called States to prepare awareness raising strategies and implement them accordingly. ${ }^{6}$ The awareness raising strategies were adopted by CBD during Nagoya Protocol's first meeting of parties (MOP1) in 2014. Subsequently, CBD presented

\footnotetext{
1 "Parties to the Nagoya Protocol," online: Convention on Biological Diversity $<$ https://www.cbd.int/abs/nagoyaprotocol/signatories/default.shtml>.

2"The Access and Benefit-sharing Clearing-house," online: Convention on Biological Diversity $<$ https://absch.cbd.int/search/nationalRecords?schema=measure $>$.

3 "EU Member Countries in Brief," online: European Union <https://europa.eu/european-union/abouteu/countries/member-countries_en>.

${ }^{4}$ The EU countries that have enacted their own ABS laws and policies are Bulgaria, Croatia, Denmark, Finland, Germany, Hungary, Malta, Netherlands, Portugal, Slovakia, Spain, Sweden, and the UK.

${ }^{5}$ http://www.cbd.int/abs/text/articles/?sec=abs-22

${ }^{6}$ ICNP-1 agenda: UNEP/CBD/ICNP/REC/1/3, 21 July 2011. During ICNP-2 (2-6 July 2012), the CBD adopted a comprehensive plan for awareness raising of stakeholders in various countries through elaborate Communication, Education and Public Awareness (CEPA) Programme (UNEP/CBD/ICNP/REC/2/6, 26 July 2012).
} 
implementation report ${ }^{7}$ of awareness raising strategy during MOP2 held in Mexico in 2016. Additionally, an array of capacity building activities has been pursued at global, regional and sub-regional level by CBD since 2010 till now (2018). However, the States seem not to have progressed adequately to educate and strengthen their own stakeholders.

Some countries have been serious in implementing the measures to educate and strengthen their own administrative wings, user corporations, research institutions and ILCs, while others are just in early phase of preparations of educating their executives. The present article explores the progress of surveyed countries in particular on implementation of the provisions made in the Nagoya Protocol regarding awareness generation, capacity building and mass education.

\section{Methodology}

This article is based on the findings of a survey conducted by authors at the Academy of International Studies of Jamia Millia Islamia ${ }^{8}$.Arguments in the present paper are supported by some observations and pertinent references. The field data was gathered from 2012 to 2015. Evaluative research methods were applied to examine the position of ILC representatives in international forums and the impact of their position on ABS laws. Nonreactive (analysis of existing documents and secondary information) ${ }^{9}$ as well as reactive (structured interviews and participant observation) research methods were employed in the study and development of this article. The methods are described as under:

\section{Sampling for Structured Interviews}

Stratified random sampling was employed for the purposes of conducting the structured interviews, with a list of potential respondents being prepared beforehand. Civil society organizations and individuals working on or advocating issues and causes relevant to ILC were first selected and contacted. The list of participants was narrowed down based on the scope of expertise and operational constraints (able to answer questions in English via email for instance). A large number of organizations, groups and individuals had been contacted. Based on participant availability, a total of 15 in-depth interviews were conducted with individuals intensively involved in their communities, and active in international forums. Individuals representing diverse organizations from various parts of the world are as mentioned in Table 1. Their responses are described in Table 2 and have been expressed in percentage format.

\footnotetext{
${ }^{7}$ Report on Progress in the Implementation of the Awareness-Raising Strategy for the Nagoya Protocol. Second meeting of the Conference of the Parties of the Convention on Biological Diversity serving as the Meeting of the Parties to the Nagoya Protocol on Access to Genetic Resources and the Fair and Equitable Sharing of Benefits arising from their Utilization, Cancun, Mexico, 4-17 December 2016. UNEP/CBD/NP/COP-MOP/2/9, 18 October 2016.

${ }^{8}$ A central university by Act of Indian Parliament: http://jmi.ac.in

${ }^{9}$ In nonreactive research the people studied are unaware that they form part of a study. They thus leave evidence of their social behaviour or actions 'naturally'. Creating nonreactive measures follows the logic of quantitative measurement, although qualitative researchers also make use of nonreactive observation. The operational definition of the variable includes how the researcher systematically notes and records of observations. Because nonreactive measures indicate a construct indirectly, the researcher needs to rule out reasons for the observation other than the construct of interest.
} 
Table 1: Particulars of Participants in the Research Work

\begin{tabular}{|l|l|l|}
\hline Participant & Organization & Country \\
\hline Emma Chippendale & $\begin{array}{l}\text { Unrepresented Nations and Peoples } \\
\text { Organization (UNPO) }\end{array}$ & Belgium \\
\hline Sali Django & $\begin{array}{l}\text { Mbororo Social and Cultural Development } \\
\text { Organization (MBOSCUDA) }\end{array}$ & $\begin{array}{l}\text { North West Region, } \\
\text { Cameroon }\end{array}$ \\
\hline Paul Joffe & Grand Council of the Crees (Eeyou Istchee) & Canada \\
\hline Babagana Abubakar & Kanuri Development Association (KDA) & Nigeria \\
\hline Alpha Beretay & World Institute for a Sustainable Humanity & Sierra Leone \\
\hline Andy Savage & Direct Sponsor (Tribal Networks) & Ireland \\
\hline Peter Watson & Legal Assistance Centre & Namibia \\
\hline Nsase Soki Maurice & Foret pour le Development Integral (FODI) & $\begin{array}{l}\text { Democratic Republic } \\
\text { of the Congo (DRC) }\end{array}$ \\
\hline $\begin{array}{l}\text { Alex Nyamujulirwa } \\
\text { George }\end{array}$ & (individual) & \begin{tabular}{l} 
Tanzania \\
\hline Imad Abdel Moniem
\end{tabular} \\
\hline Hemant Larma & (individual) & Sudan \\
\hline P. Murugan & NESAM Trust & New Delhi/India \\
\hline Amit Kumar & Citizens Foundation & Tamil Nadu/India \\
\hline Sanjay Garg & Centre for Policy Solution & $\begin{array}{l}\text { Himachal } \\
\text { Pradesh/India }\end{array}$ \\
\hline M. Sudhakar & (individual) & Jaipur/India \\
\hline
\end{tabular}

Responses were also gathered from various national focal points of governments from Asian countries in particular. The CBD's Competent National Authorities (CNAs) from 50 jurisdictions were contacted for face-to-face and email interviews. A total of 12 CNAs responded with substantial information in the questionnaire, including: India, Bangladesh, Nepal, Thailand, Vietnam, Lao PDR, Timor Leste, Brunei Darussalam, Philippines, Mongolia, China and Russia. Bahrain, Singapore, Qatar and South Korea replied that they had not yet started any preparation for ABS legislation or policy in their respective countries.

\section{Structured Interviews}

A set of questions were developed to structure the interviews (see Table 2: Survey Questions and Responses, and Table 3: Opinions of CBD/NP Parties).

Participants from Indigenous organizations/individuals (Table 2) received a questionnaire comprising of 2 relevant questions, with CBD CNAs receiving 6 pertinent questions (Table 3). The nature and number of questions were limited to maintain predominance and to respect the time investment in sufficiently responding to the survey, at times during international forums and contacted face-to-face.

\section{Results and Discussion}

The importance of education and capacity building of stakeholders lies in Article 21 and 22 of the Nagoya Protocol. Article 21 reiterates, "each Party shall take measures to raise awareness of the importance of genetic resources and traditional knowledge associated with genetic resources, and 
related access and benefit-sharing issues". So, the States are advised by Nagoya Protocol to educate their various stakeholders through variety of methods. Similarly, Article 22 provides that "Parties shall cooperate in the capacity-building, capacity development and strengthening of human resources and institutional capacities to effectively implement the Protocol in developing country Parties and Parties with economies in transition. In doing so, Parties are required to fully take into account the needs of developing country Parties and Parties with economies in transition for financial resources and facilitate the involvement of indigenous and local communities (ILCs) and relevant stakeholders". Concerning the obligations of Article 21 and 22, the Indigenous organizations/individuals were surveyed in India and other countries (Table 2).

\section{Table.2: Opinions of Indigenous Organizations and Individuals on Awareness and Capacity}

Building of ILCs in their National Contexts

\begin{tabular}{|c|c|c|c|c|}
\hline \multirow[b]{2}{*}{$\begin{array}{c}\text { QUESTIONS OF } \\
\text { OPINION SURVEY }\end{array}$} & \multicolumn{2}{|c|}{ INDIA RESPONDENTS } & \multicolumn{2}{|c|}{$\begin{array}{l}\text { INTERNATIONAL } \\
\text { RESPONDENTS }\end{array}$} \\
\hline & $\begin{array}{c}\text { Response (In } \\
\text { parenthesis: } \\
\text { Total No. of } \\
\text { Respondents - 5) }\end{array}$ & $\begin{array}{l}\text { Response } \\
\text { Percentage }\end{array}$ & $\begin{array}{c}\text { Response (In } \\
\text { parenthesis: } \\
\text { Total No. of } \\
\text { Respondents - 10) }\end{array}$ & $\begin{array}{l}\text { Response } \\
\text { Percentage }\end{array}$ \\
\hline $\begin{array}{l}\text { 1. Has your country } \\
\text { taken or been taking } \\
\text { measures for } \\
\text { awareness-raising of } \\
\text { ILCs about the } \\
\text { ABS, Nagoya } \\
\text { Protocol and their } \\
\text { rights in context of } \\
\text { access/utilization of } \\
\text { genetic resources } \\
\text { and associated ITK } \\
\text { and benefits they } \\
\text { may obtain? }\end{array}$ & $\begin{array}{l}\text { 1. } \begin{array}{l}\text { Yes, our country } \\
\text { has taken or been } \\
\text { taking measures } \\
\text { to large extent } \\
\text { (2). }\end{array} \\
\text { 2. Yes, our country } \\
\text { has taken or been } \\
\text { taking measures } \\
\text { to some extent. } \\
\text { 3. No, no such } \\
\text { measure has yet } \\
\text { been taken (1). } \\
\text { 4. I do not know (1). }\end{array}$ & $\begin{array}{ll}\text { 1. } & 40 \% \\
\text { 2. } & 0 \% \\
\text { 3. } & 40 \% \\
\text { 4. } & 20 \%\end{array}$ & $\begin{array}{l}\text { 1. Yes, our country } \\
\text { has taken or } \\
\text { been taking } \\
\text { measures to } \\
\text { large extent. } \\
\text { 2. Yes, our country } \\
\text { has taken or } \\
\text { been taking } \\
\text { measures to } \\
\text { some extent (4). } \\
\text { No, no such } \\
\text { measure has yet } \\
\text { been taken (3). } \\
\text { I do not know } \\
\text { (3). }\end{array}$ & $\begin{array}{ll}\text { 1. } & 0 \% \\
\text { 2. } & 40 \% \\
\text { 3. } & 30 \% \\
\text { 4. } & 30 \%\end{array}$ \\
\hline $\begin{array}{l}\text { 2. Has your country } \\
\text { taken or been taking } \\
\text { measures for capacity } \\
\text { building of ILCs } \\
\text { about the ABS, } \\
\text { Nagoya Protocol, } \\
\text { PIC, MAT and their } \\
\text { rights in context of } \\
\text { access/utilization of } \\
\text { genetic resources and } \\
\text { associated ITK and } \\
\text { benefits they may } \\
\text { obtain? }\end{array}$ & 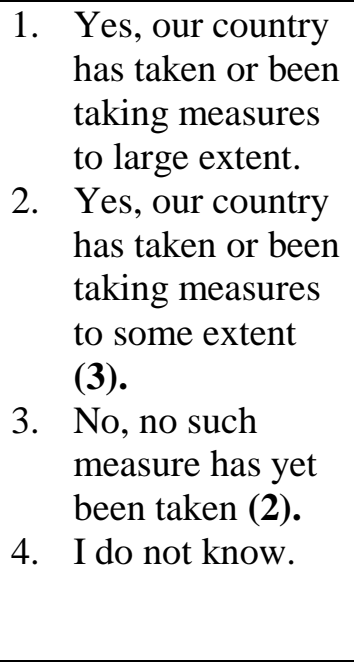 & $\begin{array}{ll}\text { 1. } & 0 \% \\
\text { 2. } & 60 \% \\
\text { 3. } & 40 \% \\
\text { 4. } & 0 \%\end{array}$ & 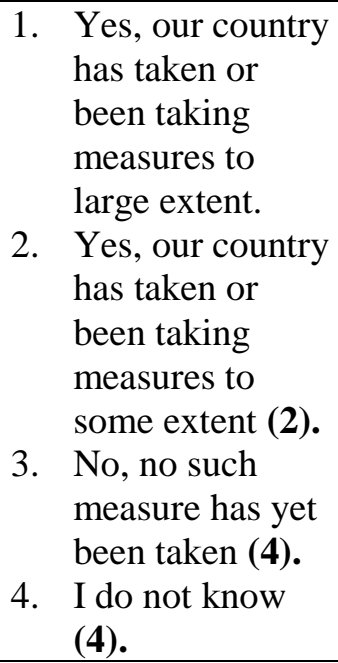 & $\begin{array}{ll}\text { 1. } & 0 \% \\
\text { 2. } & 20 \% \\
\text { 3. } & 40 \% \\
\text { 4. } & 40 \%\end{array}$ \\
\hline
\end{tabular}


Table.3: Opinions of CBD/NP Parties on Awareness and Capacity Building of ILCs [position of countries represents that of 2012]

\begin{tabular}{|c|c|c|c|c|c|c|c|c|c|c|c|c|c|c|c|}
\hline \multirow{3}{*}{ Q.No. } & \multirow{3}{*}{$\begin{array}{l}\text { QUESTIONS OF } \\
\text { OPINION SURVEY }\end{array}$} & \multirow{3}{*}{$\begin{array}{l}\text { RESPONSE } \\
\text { OPTIONS }\end{array}$} & \multirow{3}{*}{$\begin{array}{c}\text { \%age of } \\
\text { Countries' } \\
\text { Response }\end{array}$} & \multicolumn{12}{|c|}{ RESPONSES OF COUNTRIES } \\
\hline & & & & \multicolumn{3}{|c|}{$\begin{array}{l}\text { SOUTH } \\
\text { ASIA }\end{array}$} & \multicolumn{6}{|c|}{ SOUTH EAST ASIA } & \multicolumn{3}{|c|}{$\begin{array}{c}\text { NORTH } \\
\text { ASIA }\end{array}$} \\
\hline & & & & 1 & 2 & 3 & 4 & 5 & 6 & 7 & 8 & 9 & 10 & 11 & 12 \\
\hline 1. & $\begin{array}{l}\text { Is your country committed } \\
\text { about the awareness-raising } \\
\text { of your ILCs about the } \\
\text { ABS, Nagoya Protocol and } \\
\text { their rights in context of } \\
\text { access/ utilization of } \\
\text { genetic resources and } \\
\text { associated ITK and benefits } \\
\text { they may obtain? }\end{array}$ & $\begin{array}{l}\text { 1. Yes, our country } \\
\text { is very much } \\
\text { committed. } \\
\text { 2. Yes, our country } \\
\text { is somewhat } \\
\text { committed. } \\
\text { 3. I cannot say. }\end{array}$ & $\begin{array}{ll}\text { 1. } & 80.00 \% \\
\text { 2. } & 20.00 \% \\
\text { 3. } & 00.00 \% \\
\text { NAt }=2\end{array}$ & 1 & 1 & 1 & 1 & 2 & 1 & 1 & NAt & NAt & 2 & $1 \mid 1$ & 1 \\
\hline 2. & $\begin{array}{l}\text { Has your country taken or } \\
\text { been taking measures for } \\
\text { awareness-raising of ILCs } \\
\text { about the ABS and Nagoya } \\
\text { Protocol? }\end{array}$ & $\begin{array}{l}\text { 1. I am not aware. } \\
\text { 2. No, no such } \\
\text { measure has yet } \\
\text { been taken. } \\
\text { 3. Yes, some } \\
\text { measures } \\
\text { have/had been } \\
\text { pursued } \\
\text { (summed on } \\
\text { bottom of table). }\end{array}$ & $\begin{array}{ll}\text { 1. } & \\
\text { 2. } & \\
& 4.44 \% \\
\text { 3. } & \\
& 3.33 \% \\
\text { NAt }=3\end{array}$ & $\begin{array}{l}3 \mathrm{a}, \\
\mathrm{e}, \mathrm{f}\end{array}$ & NAt & 2 & 1 & 2 & & $\begin{array}{l}3 \mathrm{a}, \\
\mathrm{o}, \mathrm{c}, \\
\mathrm{d}, \mathrm{e},\end{array}$ & NAt & NAt & 3 & 2 & \\
\hline 3. & $\begin{array}{l}\text { Are the indigenous and } \\
\text { local communities being } \\
\text { passive recipients of } \\
\text { awareness packages or the } \\
\text { active players in it? }\end{array}$ & $\begin{array}{l}\text { 1. Active players } \\
\text { 2. Just passive } \\
\text { recipients } \\
\text { 3. I cannot say. }\end{array}$ & $\begin{array}{l}\text { 1. } 20.00 \% \\
\text { 2. } 30.00 \% \\
\text { 3. } 50.00 \% \\
\text { NAt }=2\end{array}$ & 1 & 3 & 2 & 2 & 3 & 2 & 1 & NAt $\mid \mathrm{I}$ & NAt & 3 & 3 & \\
\hline 4. & $\begin{array}{l}\text { Is your country committed } \\
\text { about the capacity building } \\
\text { of your ILCs on the ABS, } \\
\text { Nagoya Protocol, PIC, } \\
\text { MAT and their rights in } \\
\text { context of access/utilization } \\
\text { of genetic resources and } \\
\text { associated ITK and benefits } \\
\text { they may obtain? }\end{array}$ & $\begin{array}{l}\text { 1. Yes, our country } \\
\text { is very much } \\
\text { committed. } \\
\text { 2. Yes, our country } \\
\text { is somewhat } \\
\text { committed. } \\
\text { 3. I cannot say. }\end{array}$ & $\begin{array}{ll}\text { 1. } & 70.00 \% \\
\text { 2. } & 30.00 \% \\
\text { 3. } & 00.00 \% \\
\text { NAt }=2\end{array}$ & 1 & 1 & 2 & 1 & 1 & 1 & 1 & NAt I & NAt & 2 & 2 & \\
\hline 5. & $\begin{array}{l}\text { Are the indigenous and local } \\
\text { communities being passive } \\
\text { recipients of capacity } \\
\text { building packages or the } \\
\text { active players in it? }\end{array}$ & $\begin{array}{l}\text { 1. Active players } \\
\text { 2. Just passive } \\
\text { recipients } \\
\text { 3. I cannot say. }\end{array}$ & $\begin{array}{l}\text { 1. } 40.00 \% \\
\text { 2. } 30.00 \% \\
\text { 3. } 30.00 \% \\
\text { NAt }=2\end{array}$ & 1 & 1 & 2 & 3 & 3 & 2 & 1 & NAt I & NAt & 1 & 2 & \\
\hline 6. & $\begin{array}{l}\text { Has your country taken or } \\
\text { been taking measures for } \\
\text { capacity building of ILCs } \\
\text { on the ABS, Nagoya } \\
\text { Protocol, PIC, MAT and } \\
\text { their rights in context of } \\
\text { access/utilization of genetic } \\
\text { resources and associated } \\
\text { ITK and benefits they may } \\
\text { obtain? }\end{array}$ & $\begin{array}{l}\text { 1. I am not aware. } \\
\text { 2. No, no such } \\
\text { measure has yet } \\
\text { been taken. } \\
\text { 3. Yes, some } \\
\text { measures } \\
\text { have/had been } \\
\text { pursued. }\end{array}$ & $\begin{array}{ll}\text { 1. } & 18.18 \% \\
\text { 2. } & 45.45 \% \\
\text { 3. } & 36.36 \% \\
\text { NAt }=1\end{array}$ & 3 & NAt & 2 & 1 & 2 & 2 & 3 & 3 & 2 & 3 & 1 & \\
\hline
\end{tabular}

NAt $=$ Not Attempted 
Countries: 1. India; 2. Nepal; 3. Bangladesh; 4. Thailand; 5. Lao; 6. Vietnam; 7. Philippines; 8. Brunei; 9. Timor Leste' 10. Mongolia; 11. Russian Federation; 12. China

Options of Q.2(3): (a) Organization of meetings of indigenous and local communities; (b) Establishment and maintenance of a help desk for indigenous and local communities; (c) Promotion of voluntary codes of conduct, guidelines and best practices and/or standards in consultation with indigenous and local communities; (d) Involvement of indigenous and local communities in the implementation of Nagoya Protocol; (e) Awareness-raising of community protocols and procedures of indigenous and local communities; (f) Any other initiative.

Apparently, India and other countries have taken or been taking some measures for awarenessraising of ILCs about the ABS, Nagoya Protocol and their rights in the context of access/utilization of genetic resources and associated traditional knowledge (TK) and benefits they may obtain. In India, 40\% of the surveyed Indigenous organizations/individuals confirmed that the measures are taken or being taken to 'large extent'; while $40 \%$ of the respondents declined any such measure yet taken or being taken (Table 2, q.1). Internationally, on the other hand, $40 \%$ of surveyed Indigenous organizations/ individuals confirmed that the measures are taken or being taken to 'some extent'; while $30 \%$ of the respondents declined any such measure yet taken or being taken (Table 2, q.1). Thus, it is understood from the responses of Indigenous organizations that India and other countries have undertaken some or sporadic measures for awareness-raising of ILCs about the ABS, Nagoya Protocol and their rights in the context of access/utilization of genetic resources and associated ITK and benefits they may obtain. Still there is so much to do for all the countries. The same is validated by responses of the competent national authorities (CNAs) of India and other surveyed countries. Several countries are committed to the awareness-raising of their ILCs about the ABS, Nagoya Protocol and their rights in context of access/utilization of genetic resources and associated ITK and benefits they may obtain. ILCs are considered active players in receiving such awareness-raising activities in India.

According to the National Biodiversity Authority (NBA), India is much committed to the awareness-raising of ILCs about the ABS, Nagoya Protocol and their rights in context of access/utilization of genetic resources and associated TK and benefits they may obtain (Table 3, q.1). Majority (80\%) of the responding countries namely Nepal, Bangladesh, Thailand, Vietnam, Philippines, Russia and China said that they are 'very much committed' (Table 3, q.1). However, $20 \%$ of countries - Lao and Mongolia - responded that they are 'somewhat committed' to awareness-raising (Table 3, q.1). Similarly, India, Philippines and Mongolia have mentioned in official responses about the measures that have been taken for awareness-raising of their ILCs about the ABS, Nagoya Protocol and their rights in context of access/utilization of genetic resources and associated ITK and benefits they may obtain (Table 3, q.2). On the other hand, 44\% of responding countries - Bangladesh, Lao, Vietnam and Russia - have 'not yet taken any such measure' of awareness-raising (Table 3, q.2). Thailand and China are the countries that have expressed their 'unawareness' about the matter (Table 3, q.2). India and Philippines opined that the ILCs are active players in receiving such awareness-raising activities (Table 3, q.3). On the other hand, $30 \%$ of the respondent countries namely Bangladesh, Thailand and Vietnam said that the ILCs are just passive recipients of awareness packages (Table 3, q.3). 50\% of the responding countries (Nepal, Lao, Mongolia, Russia and China) did not express their opinion on this matter.

Similarly, the capacity building on ABS and Nagoya Protocol has been critical for the success of implementation of ABS legislation/policy. To the Indigenous organizations/individuals, a question was posed: "has your country taken or been taking measures for capacity building of ILCs about the ABS, Nagoya Protocol, prior informed consent (PIC), mutually agreed terms (MAT) and 
their rights in context of access/utilization of genetic resources and associated TK and benefits they may obtain?". Among the surveyed Indigenous organizations/individuals, $60 \%$ and $20 \%$ of CNAs from India and other countries, respectively, said that 'some measures' have been taken for capacity building of ILCs about the ABS, Nagoya Protocol, PIC, MAT and their rights in context of access/utilization of genetic resources and associated TK and benefits they may obtain (Table 2, q.2). Likewise, $40 \%$ each from India and other countries responded that 'no such measure' has taken place in their respective country (Table 2, q.2). This analysis reveals that India has taken quite many measures for capacity building of ILCs about the ABS, Nagoya Protocol, PIC, MAT and their rights in context of access/utilization of genetic resources and associated TK, while other countries are just initiating such activities. ${ }^{10}$ The same is also confirmed in the following paragraph containing the official responses of countries.

On the other hand, the competent national authorities (CNAs) of $70 \%$ of responding countries (India, Nepal, Thailand, Lao, Vietnam, Philippines and China) indicated that they are 'very much committed' to capacity building of ILCs on the ABS, Nagoya Protocol, PIC, MAT and their rights in context of access/utilization of genetic resources and associated TK and benefits they may obtain (Table 3, q.4). However, 30\% of respondent countries namely Bangladesh, Mongolia and Russia responded that they are 'somewhat committed' to capacity building (Table 3, q.4). The ILCs are reported active players in the capacity activities in India, Philippines, Nepal and Mongolia (40\% of respondent countries); while they are passive recipients in the capacity efforts of $30 \%$ of respondent countries i.e. Bangladesh, Vietnam and Russia (Table 3, q.5). Another 30\% of the countries were unaware of the matter (Table 3, q.5).It is made clear by the competent national authorities of India, Philippines, Brunei and Mongolia (36\% of respondent countries) that they have taken or been taking measures for capacity building of ILCs on the ABS, Nagoya Protocol, PIC, MAT and their rights in context of access/utilization of genetic resources and associated ITK and benefits they may obtain; whereas the competent national authorities of $45 \%$ of responding countries (Bangladesh, Lao, Vietnam, Timor and China) said that they have not yet taken any such measure to build capacities (Table 3, q.6). Thailand and Russian Federation were not confident about the same (Table 3, q.6).

A general observation of a very pertinent issue is the free flow of information and participation of ILCs in establishing the mechanisms to inform the potential users of TK about their obligations. Observing the track record of States, it may be apprehensions and reservations that the developing countries would ensure effective participation of ILCs in such mechanisms. Therefore, the process of establishing clearing houses and the information centre will be based on conventional approach with limited or no involvement of ILCs. It would also restrict the ILCs to interact with the potential users of TK. Similarly, a vital issue is the language of information flow. In fact, the language is important mean of communication and exchange of information. Most ILCs do speak and understand local or indigenous languages. On the contrary, the laws, policies, guidelines, rules, directives, administrative measures, circulars, orders, etc. of the countries are normally in national language, which may or may not be understandable to the respective ILCs. Scanty instances do exist when States circulate/communicate information to/with ILCs in their local/indigenous language. Notably, the Nagoya Protocol lacks any clause about the necessity of communicating with ILCs in their indigenous/local language. Therefore, it makes sense if the information provided to ILCs is in their local language or the language

\footnotetext{
${ }^{10}$ With the support of UNDP-GEF, India has been implementing projects on ABS in 10 provinces of the country, namely Andhra Pradesh, Gujarat, Himachal Pradesh, Sikkim, West Bengal, Goa, Karnataka, Odisha, Telangana, Tripura. Pilot projects had also been implemented in partnership of NORAD and GIZ.
} 
understandable to them. Whether the Nagoya Protocol provides or not, it is a felt need that the Parties should disclose information in a language understandable to ILCs.

\section{Conclusion}

Evidently, the analysis of results show that an intensive awareness is necessary to educate the ILCs and other stakeholders. Yet, it is commonly observed that the Parties have so far given inadequate attention to awareness-raising at large. It is understood that there is a lot to do for all the countries regarding awareness-raising and capacity building about Nagoya Protocol and ABS. Through this process is the comparatively weak, States may attain empowerment and judiciously negotiate in international forums for their sovereign rights and entitlements of their respective ILCs. Perhaps, then, it can be expected that the access and benefit sharing would be on equitable terms. The capacity building of different layers of stakeholders is given some priorities by many Parties at national level. Capacity building efforts are being undertaken at regional level as well, e.g. SouthEast Asia level, Central Asia level, Africa level, Caribbean level, etc. India has taken several measures for capacity building of ILCs about the ABS, Nagoya Protocol, PIC, MAT and their rights in the context of access/utilization of genetic resources and associated TK, while many other countries have also accomplished the same. Somewhere the ILCs are active players in the capacity activities efforts, while in other countries they are just passive recipients of such efforts. But, still there is a long way to go for the successful implementation of ABS regimes globally that will help us in sustainably managing our precious natural resources. 